Duke A.B., Shevchenko M.V. ${ }^{1}$

\title{
The healthcare preferences of pregnant women for traditional birth home and hospitals in Calabar, Nigeria
}

\author{
${ }^{1}$ School of public health, National University of Kyiv-Mohyla academy, Kyiv, Ukraine \\ 1drteka@gmail.com, shevchenko_marin@ukr.net
}

\author{
Дуке А.Б., Шевченко М.В. \\ Вподобання вагітних жінок стосовно вибору місця \\ пологів (вдома чи лікарнях) \\ в муніципалітеті Калабар, Нігерія \\ Школа охорони здоров'я, Національний університет \\ «Києво-Могилянська академія», м. Київ, Україна
}

Дуке А.Б., Шевченко М.В.

Предпочтения беременных женщин относительно выбора места родов (дома или больницах) в муниципалитете Калабар, Нигерия

Школа здравоохранения, Национальный университет «Киево-Могилянская академия», г. Киев, Украина

\section{Introduction}

High maternal mortality rates have been a problem in Calabar and in Nigeria as a whole. One Nigerian woman dies every 13 minutes - that is 109 women dying each day - from preventable causes related to pregnancy and childbirth [1].

The analysis of maternal mortality rate [2] shows improvement because of department-based interventions and shift from postpartum hemorrhage as the leading cause of death to septic abortion. Not just Calabar, a similar study conducted in Ibadan showed a similar trend [3]. Place of birth or place of death shows how grave the situation is in the country.

Skill staff utilization in Nigeria seems to be mainly for antenatal visits. Adjiwanou [4] shows how $25 \%$ of the women attending antenatal but delivers with the traditional birth attendances, resulting in the poor utilization of the primary health care centers. Perceived reasons for such is the high cost of service, poor services and distances.

Educational level, autonomy, the number of children, income level where all identified as an association with making a choice to use the primary healthcare facility. The population of 9.2 million women and girls who become pregnant each year, have the higher risk among the rural or the northern part of Nigeria, compare to the urban or the southern part of Nigeria [1]. The utilization of maternal health service is not encouraging as we seem to have the average of $60 \%$ of the entire deliveries within the country attended by unskilled health staff since 1990. Though attending antenatal is essential for a healthy pregnancy and delivery process, and while battling to ensure increase rate of attendance, there are barriers posing against timely initiation of antenatal care [5]. They notice it that women who had experience with the previous birth, are more reluctant to begin antenatal. They identified lack of knowledge, busy male partner who cannot attend with the woman, poverty and antenatal care as imposing factors. Unskilled staff practices in maternal health could result on increase maternal mortality rate.
$77 \%$ of the rural women uses traditional birth attendance services for delivery [6]. There have been governmental and nongovernmental programs geared towards training of the TBA. Okafor [7] studied the outcome of the interventions on Enugu traditional birth attendants and found that though the trained TBA refer, but they do this at grave state. There is the delay before they do referral. Low human resources might allow government compromising on the standards, giving rights to unskilled staff, who are trained and in cooperated in the health care system [8]. Lack of healthcare providers (they identified skill staff as one of the key barriers to utilization of skill birth attendants A better approach towards improving maternal mortality rate in Nigeria, such that will remain as a lasting solution to the said problem will be to work on quality human resource, not completely depending on the trained traditional birth attendants (TBA).

Many studies identified cost as one of the main reason women preferred traditional birth homes instead of the government hospital [1]. Though Nigerian market is price driven, they do not consider an exception with healthcare service, as about $61 \%$ of the women who attend antenatal services with skilled personnel return to the traditional birth homes to deliver [6].

Distance from the healthcare facility is one of reason women do not patronize the government facilities. Ashimi [9] showed how the poor category of the pregnant women could not transport themselves to the hospital because of cost and distance makes them deliver at home.

Orthodox and non-orthodox, each having its own unique service to offer cost remains the determining factor where to deliver even among those who seeks both services [10]. Fear of getting trapped in debt could make most Nigerians prefer traditional birth homes than using skilled staff services. Ashimi [9] finds the odds of giving birth at home to be higher by 3.88 in women with informal education, 0.27 higher amongst women with less than 5 deliveries compare to women with over 5 deliveries. 
While birthing is an exciting experience for women in the developed country, on the contrary it is a place of death for Nigerian women. Bryanton [11] studied the predictors of women childbirth experience and mentioned that out of the 20 predictors studied, they found a birth, awareness, support by the partner as the strongest. It is a common notion in Nigeria that they do not allow the husband into the labor room. The abuse most frequently reported was nondignified care in negative, poor and unfriendly provider attitude and the least frequent were physical abuse and detention in facilities. We saw low socioeconomic status, lack of education and empowerment of women as a factor which triggers such abuses. The poor provider training and supervision, weak health systems, lack of accountability and legal redress mechanisms influenced these behaviors of the personnel. Overall, disrespectful and abusive behavior undermined the utilization of health facilities for delivery and created a psychological distance between women and health providers [12]

Within the same country, they give women of high social standards much respects and enjoy more attention. Disrespects of patients happen most in the rural areas or among the women of low social standards [7].

Patients have their religious belief and want to have the liberty to pray [13]. A study conducted at Akpabuyo of Cross River State in Nigeria, found prayer as that strong proxemic to why pregnant women patronize the Traditional Birth Attendants. Steel

Steel [14] in his study, attempt to compare the characteristic of women who birth at home with those who birth in the hospitals, trying to understand why the difference. They assign most patients with doctors of different religious beliefs. The national bureau of statistics in their last survey, showed how much of skilled attendants services the women in Nigeria [15].

Several studies carried out through Nigeria and in Cross River state to discover why women prefer traditional birth homes to modern health facilities. According to a comparative study carried out in Calabar south local government area of Cross River state, Nigeria $25 \%$ of women patronized TBA while $27 \%$ preferred that has opposed to $69 \%$ that patronized modern health care facilities and $75 \%$ preferred modern health care facilities [16]. No such study ever done in Calabar municipal local government territories even with their different and distinct proxemics.

Purpose - to understand the awareness and healthcare preferences of pregnant women in Calabar municipal for traditional birth homes and hospitals.

\section{Materials and methods}

The research is a qualitative phenomenology research, based on interpretative phenomenology, involving focus group discussion that explored the views of the traditional birth attendants on the reason for their patients' preferences as well as indebt interviews that explored the pregnant women patronizing traditional birth homes preferences.

Focus group discussion consisted of four major steps and included (1) research design, (2) data collection, (3) analysis and (4) reporting of results.

We used purposive sampling by taking from the list of registered midwives or traditional birth attendants (TBAs) of cross-river state Association, Calabar municipality chapter. The number of participants were 15 TBAs. Focus group discussion sessions lasted for 60 (median) minutes

Midwives with not less than 5 years of experience, currently making not less than 10 deliveries in a month were considered for selection into the focus group meeting.

Our focus group discussion guide contained next information:

- $\quad$ Section A: Introductory Part;

- Section B: Main Part, which including some of the commonly-asked questions about: understanding the health system organization in Nigeria and the role of the TBA; the traditional birth attendants perception of quality service delivery and values (the exceptional ingredients that spices up their practice on their own perception); understand the preferences of pregnant women in Calabar between traditional birth homes and hospitals; to investigate the level of awareness on the different pregnancy complications; to know the proxemics that influences preferences towards choice of healthcare facility; to understand if proxemics takes priority over health risk, and reasons.

Sociodemographic characteristics of respondents were presented in the table.

Table. Sociodemographic characteristics of respondents

\begin{tabular}{|c|c|c|c|c|c|c|}
\hline \multirow[b]{2}{*}{ Respondents } & \multicolumn{2}{|c|}{ Education } & \multicolumn{2}{|c|}{ Income (in Naira) } & \multirow[b]{2}{*}{$\begin{array}{c}\text { Experience, } \\
\text { more than } \\
5 \text { year }\end{array}$} & \multirow{2}{*}{$\begin{array}{c}\text { Religion } \\
\text { Christians }\end{array}$} \\
\hline & $\begin{array}{c}P \text { - educational level } \\
\text { is up to Primary } \\
\text { school level }\end{array}$ & $\begin{array}{c}\text { T - } \\
\text { is secondary and } \\
\text { tertiary institutions }\end{array}$ & $<100 \mathrm{k}^{1}$ & $>100 \mathrm{k}$ & & \\
\hline $\begin{array}{l}\text { Registered } \\
\text { midwives or } \\
\text { traditional birth } \\
\text { attendants } \\
\text { (TBAs) }\end{array}$ & 9 & 6 & 14 & 1 & 15 & 15 \\
\hline
\end{tabular}

Focused group discussion that was moderated by a female researcher and monitored through earpiece device and live broadcast camera, as well as able to prompt the moderator through her own earpiece when necessary. Unstructured 
questionnaires, which is going to be administered by the female researcher while we stand to observe and prompt the moderator when it was necessary. Having a female moderator allowed such an atmosphere where sensitive issues discussed, without boundaries, and in-debt.

We used phenomenological method of data analysis, which involve thematic network analysis often used to reduce and explore the text, and to integrate the themes identified in the exploration. Then we read the transcript to become acquainted with the content so we can be able to identify the patterns in the data. We make the second reading and, on this reading, we apply codes to reflect the themes that emerges (basic themes). Then we group similar themes to form categories (organizing themes). The next step we cluster the themes and form global themes. In this way, we explore the data, then constructed and explored, and patterns summarized and interpreted.

\section{Results and discussion}

The focus group discussion with the TBAs is a design to answer three major questions. To identify from the midwifes point of view, what they think are the Calabar pregnant women values, preferences and proxemic. In the focus group discussion, we could identify four values of the Calabar pregnant women which were distance to the health care delivery center, affordability of the healthcare services, hospitality by the caregivers and the pride to deliver naturally without caesarean section. While a few of the respondents maintained that distance is not a factor as they receive patients far and wide, the majority insisted that most of their patients were just within the neighborhood. Delivery cost on the average among the TBA is fifteen thousand naira (This is half the country's minimum wage). Majority of the TBA agree that this amount is very much affordable for their patients and they do not complain about the cost.

A respondent said, «My patients are poor, they cannot afford the hospital bills on delivery cost, bed, drugs, which is why they patronize me for the affordable services».

Another respondent said, «I have rich patients who travel all the way from Canada and around, to deliver with me. These patients can pay their bills and in addition, will give me more gifts than the cost of the bill».

The respondents individually have their own unique way of hosting their patients. They all agree to good and quality hosting of their patients as one value of a Calabar pregnant woman which they know about and exploring as a spice to their quality services. Exploring the different worlds, we found that majority show hospitality to their patients by giving them food to eat, freedom to use the amenities for free (such as water and electricity), access to the kitchen with ability to cook and stay just like in a home. Others mentioned giving financial help, marriage counselling and caring for the dependents of their patients. «I will buy bean cake and give to my patients' child, then I will watch to see when she goes to show to the mother saying Mama bought for me, and the mother cuts some piece to eat, through that I understand the mother also is hungry, and I will go make food for the mother».

A respondent said, «I take my patients as my own daughters».
TBAs says that one value of Calabar pregnant women is to deliver naturally without caesarean section. They also discussed the ongoing stigmatization in Calabar against women who deliver by CS. Though 14 out of 15 of the respondents speaking on their opinion about CS maintained that it is a good service. One respondent said, «The same God who kept me here as a TBA for the work I do, kept the doctors in the hospital for what is outside of my reach to do».

Notwithstanding, one of the TBAs took a stand to express that she is against sectio Caesarea (CS), she said, «It was not design by God for a woman to pass through CS before delivery. Therefore, I pray with my patients against it as it is not the will of God for the women»».

This respondent insisted that she can refer her patients to the hospital when she identifies danger signs as they trained her, but do strongly wish she delivers without CS. About $13.3 \%$ of the TBAs considers that distance is not why their patients patronizes them while others were of the strong opinion that it is because of the proximity which makes them receive most of their patients in the night hours because they can not make it to the hospital. The three most interesting saying were:

«Distance is not the reason as I get patients as far as from 8 miles and Calabar south»,

«Most of my patients are within the community».

The TBAs considers their services to be affordable for the patients. Though

they mentioned that their patients are mostly the poor, which makes them set the cost of the services at a much more affordable price. Notwithstanding, one of the TBAs insisted that she has over time received extremely poor patients who can barely afford her services. Her strategy as she discussed is to allow the patient go without paying for the services but in return, the patient will introduce other patients to her who can afford or even pay much more than the set fee for service.

93.3\% still maintain that all of their patients could afford their services and here are some of the most interesting saying during the discussion, «There are very rich patients who even pay more than the supposed charges. Low cost is not the reason»

«I do not see any rich person come to patronize me, only the poor who cannot afford the bills in the hospitals»

«Most of my patients could barely afford the needful talk less of the supposed bills. They stay for months after delivery and some are discharged without paying»

The TBAs in attendant all agree that Hospitality is one of the most prestigious value of a Calabar pregnant woman. Supplies of food, consumables and some of the immediate items that the new born requires, is considered as hospitality by the TBAs.

Here are some of the saying when speaking about hospitality: «I give my patients food and other needful»

«I stay with them like a mother. They are just like my own children»

«They have the liberty to stay with me as long as they want. I make my place like a home».

Majority of the TBAs in Calabar during the focused group discussion did not agree to the fact that Calabar pregnant women have any fear for Cesarean section. Only $6.7 \%$ of the TBAs respondents admit that Calabar pregnant women have 
fear for CS and it is a value for the Calabar pregnant woman to deliver without CS. Here are some of the sayings:

«I pray with my Patients against CS. It is not the will of God for women»

«CS by the doctors is to help save the lives of women.

When it is needed, I do not hesitate»

«It is a value for a woman to deliver her own baby without CS but when needed, I do not delay because this is life and death thing»

About Preferences of the Calabar pregnant women, from the perspective of their Traditional Birth Attendants (TBAs), «Patience» in their own word, which asking further to understand what they mean by patience, the described absence of any form of abuses was first of the identified preferences mentioned. These are some of what they said:

«Hospital rushes women for CS and do not give them enough time to try labor. We are patience with them»

«Women Prefer me because I can be patience with them showing them, I share in their pains»

«God gives me a heart of patience because this work requires much patience»

Digging deeper to understand the word "Patience which seems to appear in their statements, here are some of the explanations:

"Women tell me how nurses beat them in the hospital while in labor, but in my place, I pet them because they bring me money»

«My patient's husband told me how he was practically forced to sign consent and the wife was rushed in for surgery, but he feels that if they were a bit patience to wait, the wife would have delivered naturally»

«A woman in labor spit to my face, I cleaned it off and helped her deliver. The next day she apologized to me. If it was with the nurses in the hospital, they will abandon her»».

Just as with patience, $100 \%$ of the TBAs in attendant, mentioned that the reason for why Calabar pregnant women prefer them to the government hospital is because of the quality care they render to the women. Here are some of the sayings:

«I know women don't get the kind of care we give them in the hospital. I stay with my patients, pet them until they deliver»

«My patients are just like my daughters, when I cook, I share my food with them and make them feel homely. This what this work is all about»

«Some women can be stubborn when in pains. Quality to them is also the ability to stay with them in their pains».

About $93.3 \%$ of the TBAs believe they were called by God for the work they do. Though not exactly admitting to the fact that they have special gifts, such as, "Gifted hands" which is why they can take delivery and care for the women, but rather redirecting the discussion towards the fact that they are rather blessed with a good heart to be patience with the women.

Here are some of the sayings:

«I was called by God for this work. I don't believe that if someone is not called, can do this work» patience»

«Anyone can be a TBA. You only need to be very this work»
We want to know if there is any existing religious, cultural believes that demand the Calabar women to use the TBAs as we heard a story from one of the TBAs on how one of the Calabar woman in Canada travelled back to Calabar just to deliver with her TBA. Prayer was the only identified proxemic, responsible for why Calabar pregnant women uses the TBA. There is no known law, cultural or religious believe, which conditions a Calabar pregnant woman to the use of TBA or any particular health care provider.

The entire TBAs on attendant admits that the women patronizes them because of the prayers, and some of them still delivers in the hospital but will visit them for antenatal care which is done weekly with fasting and prayers. Here are some of the interesting sayings:

«Prayer is the key to success in this work»

«Most of my patients deliver in the hospital but they come to me during the course of their pregnancy because we I pray with the pregnant women»

«We have fasting and prayers every week with my patients and it is the bond that keeps my patients with me».

Results showed that there is diversity when considering the individual's values. But from the vast number of values mentioned, during the exploration, we picked the commonly said by all the respondents. These are distance, cost, hospitality and the ongoing stigmatization among women who went through cesarean section.

Our findings show that majority of the traditional birth attendants do not believe that distance could be a value to the Calabar pregnant women, and it could be the reason Calabar pregnant women patronizes them as the majority say because most women came from very far distances to patronize them. Communities with a trained Traditional Birth Attendants, use the center as their local Primary healthcare as these TBAs attend not only to pregnant women, but can identify such a common ailment as malaria and can treat the husband of their pregnant patients. A TBA in a community is a value for the people.

Hospitality as a value for the Calabar pregnant women, show that part of quality to a Calabar pregnant woman is hospitality. TBA allows their patients use their kitchen for cooking whatever appeal their taste. There are no kitchens in hospitals, and patients depend on their relatives bringing food from home, which they eat in the ward. The TBA look after not only the patients, but the patient's dependents. The TBA also advises the patients on how to take care of their home even with the pregnancy. They do none of these in the hospitals, yet they are values of Calabar pregnant women.

The TBAs in their focused group discussion attempted to emphasize on the importance of patience. Though they all consider that without patience, one cannot be a TBA and it is the secret of their patients' attraction.

There seem to be the general notion that nurses yells at the patients and often patients get physically abused because of impatience. Such forms of abuses do not exist in the TBA centers and it forms one of the core reasons for Calabar pregnant women preferences. Diving into the world of the respondents, they consider absence of any form of abuse on patients as being patience.

In the focus group discussion with the TBAs, they rather did not see themselves as some special people, with special gifted hands by God, but as humble servants of God who is 
there to serve the people. They were not even comfortable discussing how special they are, and the wonderful things they do for the community, rather believing that anyone with enough patience can do the job.

The study of healthcare preferences of pregnant women in Calabar municipal allowed making the following conclusions:

- There is no one «standalone» reason for the use of traditional birth attendant homes instead of the government hospital, but there is a mix of the reasons with some outstanding factors that influences Calabar pregnant women choice on the use of traditional birth homes instead of government hospitals;

- Closeness to the healthcare service provider, affordability of service, hospitality and pride of delivering naturally are the identified values for Calabar pregnant women;

- The identified preferences between the use of Traditional Birth attendants and hospitals are patience by the care giver, quality nursing care of the patients and the believe that Traditional Birth Attendants have "Gifted hands" to take delivery.

\section{References}

1. Wekesah F, Izugbara C. Maternal Health in Nigeria: Facts and Figures. Fact Sheet. 2017 June;1:1-4.

2. Agan TU. Trend and Causes of Maternal 5-year retrospective study (2010-2014) at the University of Calabar Teaching Hospital, Calabar, Nigeria. Open Access Maced J Med Sci. 2018 Jun 20; 6(6):1153-6.

3. Adegoke AA, Campbell M, Ogundeji MO, Lawoyin T, Thomson AM. Place of birth or place of death: an evaluation of 1139 maternal deaths in Nigeria. Midwifery. 2013 Nov; 29(11):115-21.

4. Adjiwanou V, Legrand T. Does antenatal care matter in the use of skilled birth attendance in rural Africa: a multicountry analysis. Soc Sci Med. 2013 Jun; 86:26-34.

5. Hagey J, Rulisa S, Pérez-Escamilla R. Barriers and solutions for timely initiation of antenatal care in Kigali, Rwanda: Health facility professionals' perspective. Midwifery. 2014 Jan; 30(1); 96-102.

6. Okonofua F, Ntoimo L4, Ogungbangbe J, Anjorin S, Imongan W, Yaya S. Predictors of women's utilization of primary health care for skilled pregnancy care in rural Nigeria. BMC Pregnancy Childbirth. 2018 Apr 18;18(1):106.

7. Okafor II, Arinze-Onyia SU, Ohayi SAR, Onyekpa JI, Ugwu EO. Audit of childbirth emergency referrals by trained traditional birth attendants in Enugu, Southeast, Nigeria. Ann Med Health Sci Res. 2015 Jul-Aug; 5(4): 305-310.

8. Adewemimo AW, Msuya SE, Olaniyan CT, Adegoke AA. Utilisation of skilled birth attendance in Northern Nigeria: a cross-sectional survey. Midwifery. 2014 Jan;30(1): 7-13.

9. Ashimi AO, Amole TG. Prevalence, reasons and predictors for home births among pregnant women attending antenatal care in Birnin Kudu, North-west Nigeria. Sex Reprod Healthc. 2015 Jan 23; 6(3):119-125.

10. Okafor IP, Sekoni AO, Ezeiru SS, Ugboaja JO, Inem V.Orthodox versus unorthodox care: A qualitative study on where rural women seek healthcare during pregnancy and childbirth in Southwest, Nigeria. Malawi Med J. 2014 Jun; $26(2): 45-9$.

11. Bryanton J, Gagnon AJ, Johnston C, Hatem M. Predictors of women's perceptions of the childbirth experience. J Obstet Gynecol Neonatal Nurs. 2008 Jan-Feb;37(1):24-34.

12. Ishola F, Owolabi O, Filippi V. Disrespect and abuse of women during childbirth in Nigeria: A systematic review. PLoS One. 2017 Mar 21;12(3):e0174084.

13. Akpabio II1, Edet OB, Etifit RE, Robinson-Bassey GC. Women's preference for traditional birth attendants and modern health care practitioners in Akpabuyo community of Cross River State, Nigeria. Health Care Women Int. 2014 Jan;35(1):100-9.

14. Steel A, Adams J, Frawley J, Broom A, Sibbritt D. The characteristics of women who birth at home, in a birth centre or in a hospital labour ward: A study of a nationally-representative sample of 1835 pregnant women. Sex Reprod Healthc. 2015 Oct;6(3):132-7.

15. Multiple Indicator Cluster Survey 2016-17. Survey Findings Report: National Bureau of Statistics, UNICEF; 2018,538 p. Report №: 1 .

16. Efunkoya AA, Omeje KU, Amole IO, Osunde OD, Akpasa IO. A review of cleft lip and palate management: Experience of a Nigerian Teaching Hospital.Afr J Paediatr Surg. 2015 Oct-Dec;12(4):257-60.

Дата надходження рукопису до редакції: 25.04.2019 р.

Purpose - to understand the awareness and healthcare preferences of pregnant women in Calabar municipal for traditional birth homes and hospitals.

Materials and methods. The research is a qualitative phenomenology research, based on interpretative phenomenology, involving focus group discussion that explored the views of the traditional birth attendants on the reason for their patients' preferences as well as indebt interviews that explored the pregnant women patronizing traditional birth homes preferences. Focus group discussion consisted of four major steps and included research design, data collection analysis and reporting of results. 
We used purposive sampling by taking from the list of registered midwives or traditional birth attendants (TBAs) of cross-river state Association, Calabar municipality chapter. The number of participants were 15 TBAs.

Results. Results showed that there is diversity when considering the individual's values. The TBAs in their focused group discussion attempted to emphasize on the importance of patience. Though they all consider that without patience, one cannot be a TBA and it is the secret of their patients' attraction.

Conclusions. There is no one «standalone» reason for the use of traditional birth attendant homes instead of the government hospital, but there is a mix of the reasons with some outstanding factors that influences Calabar pregnant women choice on the use of traditional birth homes instead of government hospitals.

Key words: pregnant women, traditional birth attendance, preferences.

Мета - виявлення вподобань вагітних жінок щодо вибору місця пологів (вдома чи лікарнях) та вивчення причин.

Матеріали і методи. Дослідження базується на результатах групового глибинного інтерв'ю, сфокусованого на досліджуваній проблемі, спрямоване на визначення вподобань вибору місця пологів вагітними жінками, які мешкають в муніципалітеті Калабар Нігерії. Матеріал зібрано за допомогою фокус груп серед постачальників послуг (акушерок). В дослідженні взяли участь 15 акушерок з досвідом не менше 5 років. Обговорення у фокус-групі складалося 3 чотирьох основних етапів і включало розробку дизайну досліджень, збір даних, аналіз та звітування про результати.

Результати і обговорення. Результати показали, що вподобання вагітних жінок щодо вибору місця пологів (вдома чи лікарнях) відрізняються. Однак всі респонденти вказали, що при виборі місця пологів значну роль відіграють відстань до постачальника таких послуг, вартість пологів, ставлення до пацієнтів та наявність негативного досвіду (грубе ставлення фізичного чи психологічного характеру з боку персоналу лікарні) серед жінок, які раніше народжували шляхом оперативного розродження (кесарів розтин).

Висновки. Результати дослідження показали, що немає жодної «стандартної» причини, яка б формула вподобання вагітних жінок муніципалітету Калабар (Нігерія) щодо вибору місця пологів. Однак виявлено окремі вподобання, які впливають на вибір вагітних жінок народжувати вдома, а не в лікарнях.

Ключові слова: вагітні жінки, пологи вдома, вподобання.

Цель - выявление предпочтений беременных женщин отнсительно их выбору места родов (дома или больницах) и изучение причин.

Материалы и методы. Исследование базируется на результатах группового глубинного интервью, сфокусированного на исследуемой проблеме, направленное на определение предпочтений выбора места родов беременными женщинами, которые проживают в муниципалитете Калабар Нигерии. Материал собран с помощью фокус групп среди поставщиков услуг (акушерок). В исследовании приняли участие 15 акушерок с опытом не менее 5 лет. Обсуждение в фокус-группе состояло из четырех основных этапов и включало разработку дизайна исследования, сбор данных, их анализ и отчетность о результатах.

Результаты и обсуждение. Результаты показали, что предпочтения беременных женщин относительно выбора места родов (дома или больницах) отличаются. Однако все респонденты указали, что при выборе места родов значительную роль играют расстояние до поставщика таких услуг, стоимость родов, отношение к пациентам и наличие негативного опыта (грубое отношение физического или психологического характера со стороны персонала больницы) среди женщин, которые ранее рожали путем оперативного родоразрешения (кесарево сечение).

Выводы. Результаты исследования показали, что нет никакой «стандартной» причины, которая бы формировала предпочтения беременных женщин муниципалитета Калабар (Нигерия) по выбору места родов. Выявлены отдельные предпочтения, которые влияют на выбор беременных женщин рожать дома, а не в больницах.

Ключевые слова: беременные женщины, роды дома, предпочтения.

Конфлікт інтересів: відсутній.

Conflicts of interest: authors have no conflicts of interest to declare.

\section{Відомості про авторів}

Асуко Дуке - Магістр освітньої програми «Менеджмент в охороні здоров'я» Школи охорони здоров'я Національного університету «Києво-Могилянська академія»; вул. Волоська, 10, м. Київ, 02000, Україна. +380 (44) 425-77-69, 1drteka@gmail.com.

Шевченко Марина Вікторівна - д.мед.н., с.н.с., доцент Школи охорони здоров’я Національного університету «КиєвоМогилянська академія»; вул. Волоська, 10, м. Київ, 02000, Україна.

+380 (44) 425-77-69, shevchenko_marin@ukr.net. 